グラフェンを用いた中赤外光検出とスピン伝導デバイス*

町田 友樹 $* 1, * 2 \cdot$ 増㴊 覚 $* 1, * 2 \cdot$ 大貫 雅広*1

荒井 美穂*1 $\cdot$ 山口 健洋*1 $\cdot$ 井上 義久 $* 1$

守谷頼*1 ·渡邊 賢司*3 ·谷口尚*3

\title{
Graphene-based Mid-infrared Photodetectors and Spin Transport Devices
}

Tomoki MACHIDA*1,*2, Satoru MASUBUCHI*1,*2, Masahiro ONUKI*1,

Miho ARAI*1, Takehiro YAMAGUCHI*1, Yoshihisa INOUE*1,

Rai MORIYA*1, Kenji WATANABE*3 ${ }^{* 3}$ and Takashi TANIGUCHI*3

\author{
*1 Institute of Industrial Science, University of Tokyo, 4-6-1 Komaba, Meguro-ku, Tokyo 153-8505, Japan \\ *2Institute for Nano Quantum Information Electronics, University of Tokyo, 4-6-1 Komaba, Meguro-ku, Tokyo 153-8505, Japan \\ ${ }^{* 3}$ National Institute for Materials Science, 1-1 Namiki, Tsukuba-shi, Ibaraki 305-0044, Japan
}

(Received May 16, 2014, Accepted September 11, 2014)

\begin{abstract}
High-mobility graphene is fabricated on hexagonal boron nitride (h-BN) using a micromechanical cleavage and dry transfer technique. We demonstrate the photovoltaic effect due to the cyclotron resonance in graphene $/ \mathrm{h}-\mathrm{BN}$ under quantized Hall regime and the electrical spin injection into graphene through a single-layer h-BN tunnel barrier.
\end{abstract}

\section{1. グラフェン〜複合原子層}

グラフェンは炭素原子が蜂の巣格子状に配列された単原子 層膜であり，K 点近傍で線形なエネルギー分散となる特異 なバンド構造を有する1). グラフェン中のキャリアは相対論 的な粒子であるディラックフェルミオンとして振る舞い, Klein トンネリング2), 半整数量子ホール効果 ${ }^{3)}$ など, グラ フェン固有の量子輸送現象が観測される. エレクトロニクス 応用の観点からも, 半導体では実現できない高いキャリア移 動度4) や熱伝導度等の特異な物性が魅力的であり, 幅広い分 野で注目されている新規材料系である5). 最近ではディラッ ク電子系であるグラフェンに加え, 絶縁体の六方晶窒化ホウ 素 $(\mathrm{h}-\mathrm{BN})$ や半導体の $\mathrm{MoS}_{2}, \mathrm{WS}_{2}, \mathrm{WSe}_{2}$ など, 様々な物 質の原子層薄膜が作製されている. 複合原子層に抢ける新規 物性の発現や新機能素子の実現を目指した原子層科学の進展 が期待されている.

本稿では, メカニカル䢃開と原子層転写法により作製した グラフェン $/ \mathrm{h}-\mathrm{BN}$ 複合構造を利用した我々の研究を紹介す る. $\mathrm{h}-\mathrm{BN}$ を原子レベルで平坦な基板として利用したグラフ ェン/h-BNでは, 外因的なキャリア散乱が抑制されて極め て高いキャリア移動度が得られるとともに, グラフェン固有 の物理現象がより明瞭に観測される. 強磁場中で形成される ランダウ準位のエネルギー間隔に対応する光を照射すること で, サイクロトロン吸収による光起電力効果が観測され た6). さらに単原子層 h-BNをトンネルバリアとして利用す ることにより, 強磁性電極からグラフェンへのスピン注入も 実現した7).

* 平成25年11月 28 日 第54回真空に関する連合講演会で発表

*1 東京大学生産技術研究所（干153-8505 東京都目黒区駒場 4-61)

*2 東京大学ナノ量子情報エレクトロニクス研究機構（干1538505 東京都目黒区駒場 4-6-1)

*3 物質 · 材料研究機構（于305-0044 茨城県つくば市並木 1-1）

\section{2. 高移動度グラフェン/h-BN の作製}

スコッチテープによるメカニカル䢃開法は非常に原始的で はあるが, 最も高いキャリア移動度が得られるグラフェン作 製手法である。しかし，シリコン基板上に転写されたグラフ ェンは，シリコン基板表面の $\mathrm{SiO}_{2}$ の影響により，グラフェ ンの本質的な高いキャリア移動度を得ることができない8). その解決策の 1 つはグラフェンを $\mathrm{h}-\mathrm{BN}$ 上へ転写する手法 である ${ }^{9)}$. h-BN はグラフェンと同様，䢃開法により原子レ ベルで平坦な面を出すことが可能であり, グラフェンとの格 子不整合が $2 \%$ 以下, 荷電不純物濃度が極めて低い, $\mathrm{SiO}_{2}$ と比べて高い光学フォノンエネルギーを持つという特徵によ り，基板由来の外因的なキャリア散乱を抑制することができ る (Fig. 1).h-BN 上グラフェンは同じ目的で実現された グラフェン宙づり構造(4)よりも安定な構造であり, 素子設計 の自由度が高い点が長所である.

具体的には, スコッチテープを用いたメカニカル䢃開法に より, ポリマー膜コートしたシリコン基板上へ単層グラフェ ンを作製する．同様にスコッチテープを用いた䢃開法により

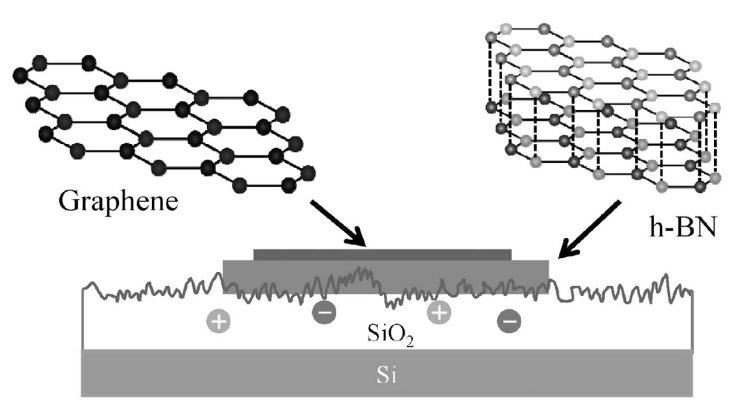

Fig. 1 A schematic representation of graphene/hexagonal boron nitride fabricated on Si substrate using the mechanical exfoliation and dry transfer technique of atomic layers. 
h-BN をシリコン基板上へ作製する．いずれも光学顕微鏡観 察により原子層数を同定する. シリコン基板上のグラフェン をポリマー膜ごと剥がし取り，顕微鏡下で位置合わせしなが ら h-BN 上へ転写し (Fig. 2), ポリマー膜除去, アニール, 電子線リソグラフィー, 酸素プラズマエッチング, 金属電極 蒸着の過程により, 高移動度グラフェン/h-BN 素子を作製 する．同一原子層 $\mathrm{h}-\mathrm{BN}$ 上にグラフェンが転写されている ため, h-BN は 1 原子層のステップもない平坦な下地の役割 を果たす。

グラフェンはバックゲート電圧の印加により両極性の電界 効果を示す（Fig. 3 (a)). Si 基板上に作製されたグラフェ ンに比べ, $\mathrm{SiO}_{2}$ との相互作用に起因する外因的なキャリア 散乱が抑制されるため, 1 桁以上高いキャリア移動度が得ら れている. 電気伝導度のバックゲート電圧依存性を長距離ポ テンシャル散乱体と短距離ポテンシャル散乱体によるキャリ ア散乱を考慮して解析することにより10), グラフェン/h$\mathrm{BN}$ の平均自由行程がバックゲート電圧の関数として得られ る (Fig. 3 (b)). キャリアの平均自由行程は低温では数 $\mu \mathrm{m}$, 室温でも $1 \mu \mathrm{m}$ 程度の巨視的な大きさとなっており, $\mathrm{M}$ 字型の特異的な磁気抵抗効果 ${ }^{10)}$, Fabry-Perot 干渉および Klein トンネリング11)など，バリスティック伝導に起因する グラフェン固有の現象を観測している.

\section{3. サイクロトロン吸収による中赤外光検出}

グラフェンに垂直磁場を印加すると, サイクロトロン運動 が量子化されてランダウ準位が形成される. ランダウ準位の エネルギー間隔は中赤外 $\mathrm{THz}$ 帯の光のエネルギーに対応 するため, サイクロトロン吸収による電気伝導特性の変化に

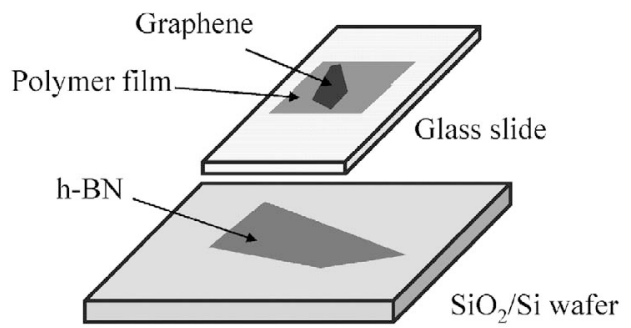

Fig. 2 A schematic representation of the dry transfer process of atomic layers.
より光検出が可能である. 本節では, グラフェン/h-BNに おけるサイクロトロン吸収を利用した中赤外光検出について 説明する.

\section{1 グラフェンにおけるランダウ量子化}

グラフェンに垂直磁場 $B$ を印加することにより，ランダ ウ準位が形成される. そのエネルギーはランダウ準位指数 $n$, プランク定数 $h$, フェルミ速度 $v_{\mathrm{F}}$, 単位電荷 $e$ を用いて,

$$
E_{n}=\operatorname{sgn}(n) v_{\mathrm{F}} \sqrt{2 e \hbar|n| B}
$$

と記述される (Fig. 4(a)). 一方, 半導体二次元電子系にお けるランダウ準位は有効質量 $m^{*}$ を用いて,

$$
E_{n}=\hbar \frac{e B}{m^{*}}\left(n+\frac{1}{2}\right)
$$

\section{と記述される(Fig. 4(b)).}

ランダウ準位のエネルギー間隔に対応する光（中赤外光〜 $\mathrm{THz}$ 波) が照射されるとサイクロトロン吸収が生じるため, それに伴う電気伝導特性の変化により光検出が可能となる. 強磁場中の半導体二次元電子系では, 同様の原理を用いて極 めて高感度の量子ホール $\mathrm{THz}$ 光検出素子 ${ }^{12)}$ や単一光子検出 素子13)が実現されており, 強磁場中グラフェンも高感度光 検出素子としての応用が期待できる. さらに, グラフェンに おけるディラックフェルミオンのランダウ準位は二次元電子 系のランダウ準位と顕著な違いがあり，(i) ランダウ準位間 隔が極めて大きい, (ii) ランダウ準位間隔がランダウ準位指
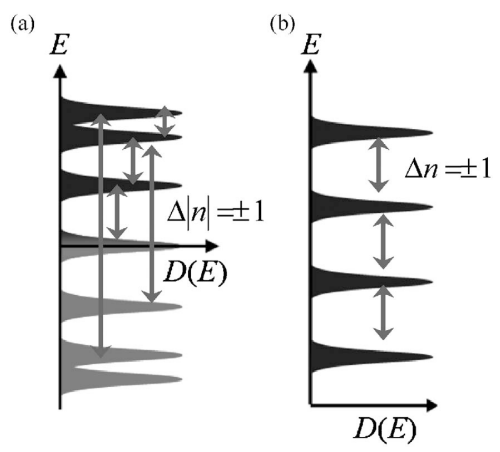

Fig. 4 (a) A schematic representation of Landau level of Dirac fermion in graphene. (b) Landau level of electron in a semiconductor two-dimensional electron system.
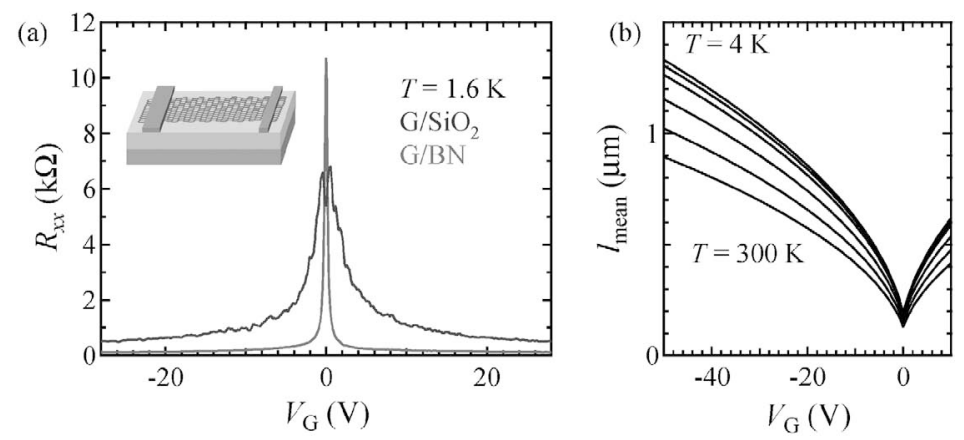

Fig. 3 (a) Longitudinal resistance as a function of back-gate voltage measured in graphene $/ \mathrm{h}-\mathrm{BN}$ and graphene $/ \mathrm{SiO}_{2}$. Inset represents a graphene Hall-bar device. (b) Carrier mean-free path derived from transport measurements at $T=4-300 \mathrm{~K}$. 
数に対して非等間隔, (iii) 電子のランダウ準位とホールのラ ンダウ準位の間で光学遷移が可能（グラフェンにおける選択 則 $\Delta|n|= \pm 1$, 電子系に打ける選択則 $\Delta n= \pm 1$ ) という特 徵を有する. 従って, 半導体二次元電子系の利用に比べて, より高温・広波長帯域で動作する高感度光検出が期待される.

\section{2 中赤外光応答}

メカニカル䢃開法と原子層転写技術を用いて $\mathrm{h}-\mathrm{BN}$ 基板 上に単層グラフェンを作製し, 電子線リソグラフィーと酸素 プラズマエッチングを用いてホールバー素子を作製した. グ ラフェンに垂直磁場を印加することによりランダウ準位が形 成され，ディラックフェルミオンの量子ホール効果が観測さ れる. ランダウ準位充填率 $v=2,6,10, \cdots$ において縦抵抗值 が $R_{x x}=0$, ホール抵抗值が $R_{\mathrm{H}}=h / 2 e^{2}, h / 6 e^{2}, h / 10 e^{2}, \cdots に$ 量 子化される (Fig. 5(a)).

強磁場下 $(B=8 \mathrm{~T})$ でグラフェン $/ \mathrm{h}-\mathrm{BN}$ ホールバー型素 子に対し, 波長 $\lambda=10.6 \mu \mathrm{m}$ の中赤外光を照射した. $\mathrm{CO}_{2}$ レーザ光源からの中赤外光は, 光ファイバーとライトパイプ を介して温度可変インサート中に設置したグラフェンホール バー素子に照射されている.レーザ光はチョッパーによって 変調し, 光照射による抵抗值変化をロックイン検出すること により光応答信号を測定した.

Fig. 5 (b) は $T=60-150 \mathrm{~K}, I=0 \mathrm{~A}$ に打ける光応答信号 $\Delta V$ のバックゲート電圧 $V_{\mathrm{G}}$ 依存性を示す. $v= \pm 2$ の量子 ホール状態において光応答信号が観測された. Fig. 5 (d) は $T=5-25 \mathrm{~K}, I=100 \mathrm{nA}$ に扔ける光応答信号 $\Delta V$ の $V_{\mathrm{G}}$ 依存 性を示す. 量子ホール状態に抢ける光応答に加え, 量子ホー ル状態間遷移領域 $v=-6 \Leftrightarrow-2,-2 \Leftrightarrow+2,+2 \Leftrightarrow+6$ でも 光応答信号が観測されている.

実験結果から，2 種類の異なるメカニズムに起因する光応 答信号が観測されていると考えられる. 一方の光応答信号は 量子ホール状態で生じ, もう一方の光応答信号は量子ホール
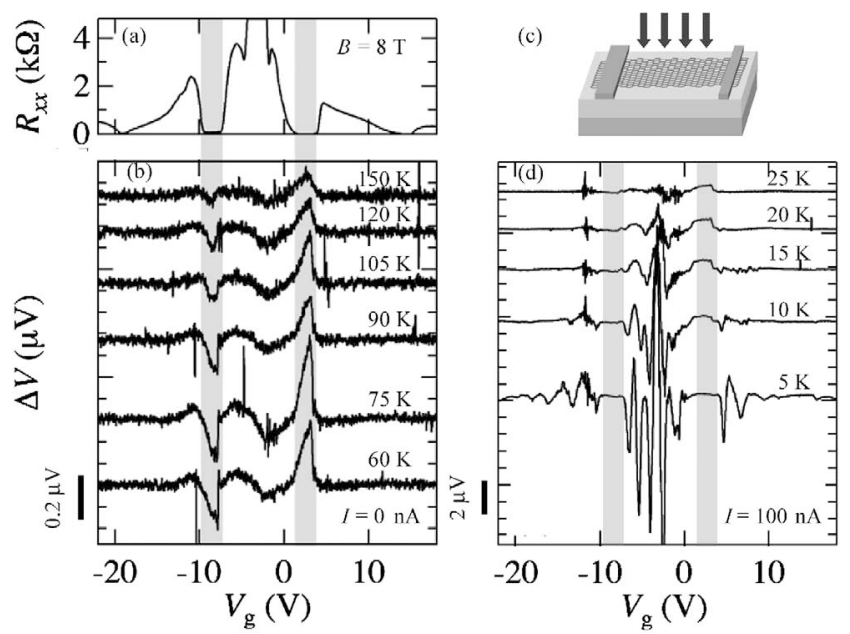

Fig. 5 (a) Longitudinal resistance as a function of back-gate voltage $V_{\mathrm{g}}$ measured at $T=25 \mathrm{~K}$ and $B=8 \mathrm{~T}$. (b) Photoresponse measured with $I=0 \mathrm{nA}$ for the incident photon wavelength of $\lambda=10.6 \mu \mathrm{m}$. Each curve was offset for clarity. The shaded areas indicate the positions of $v= \pm 2$ quantum Hall regime. (c) A schematic of the graphene Hall bar device. (d) Photoresponse measured with $I=100 \mathrm{nA}$.
状態間遷移領域で生じている．両者は常に共存しているが， 高温・低バイアス電流の条件下では前者が支配的になり, 低 温・高バイアス電流の条件下では後者が支配的になる.

量子ホール状態に打りる光応答は, ランダウ準位 $v=-1$ $\Leftrightarrow 0, \quad 0 \Leftrightarrow+1$ のエネルギー間隔が，照射光 $(\lambda=10.6 \mu \mathrm{m})$ の エネルギーに一致する磁場で生じている. 光の波長をわずか に変化させると, Fig. 6 に示すように, 光応答信号が最大 となる磁場が系統的に変化し, 量子ホール状態で観測される 光応答信号がサイクロトロン共鳴吸収によって生じているこ とを示している. 一方, 量子ホール状態間遷移領域の光応答 信号は波長に対する共鳴的な磁場依存性を示さず，サイクロ トロン吸収による光応答信号ではない.

両者の違いは Fig. 7 (a)（b)に示すように, 光応答信号 $\Delta V$ のバイアス電流 $I$ 依存性で明瞭に示される. 量子ホール 状態でのサイクロトロン吸収に起因する光応答信号は電流值 に依存せず, 光起電力効果である. 一方, 量子ホール遷移領 域での光応答信号は電流值に対して比例して抢り, ボロメト リック効果による光応答である。つまり, 中赤外光吸収によ り電子温度が上昇することにより抵抗值が変化し, バイアス 電流值に比例する光応答信号が得られている.

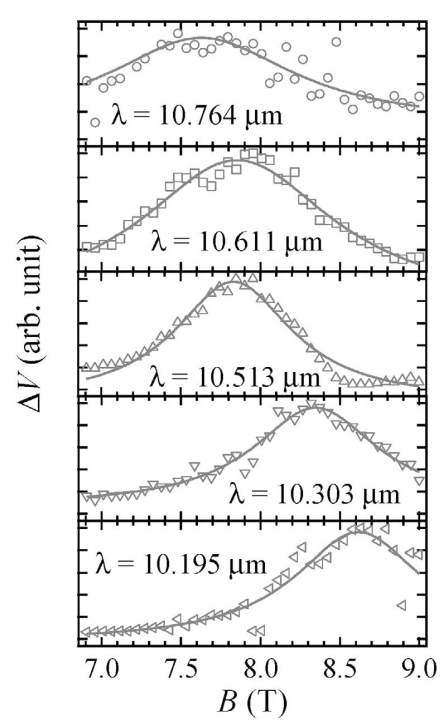

Fig. 6 Photoresponse as a function of magnetic field for various incident light wavelength corresponding to the photon energy of $115-122 \mathrm{meV}$ (from top to bottom).
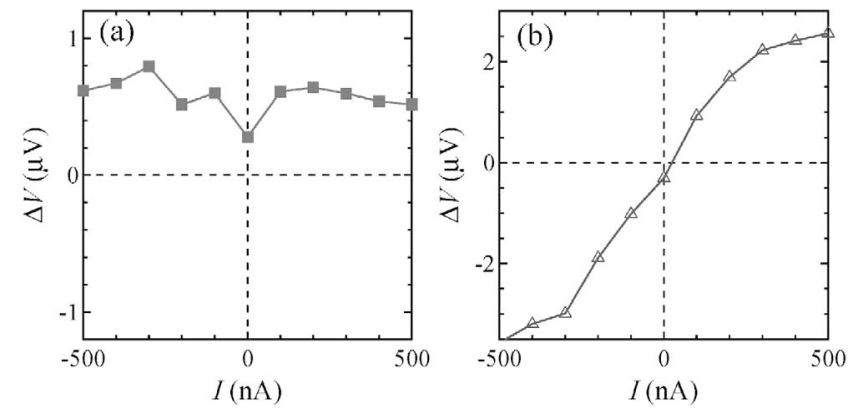

Fig. 7 (a) Photoresponse as a function of $I$ at $15 \mathrm{~K}$. (a) $v=2$ quantum Hall regime. (b) $v=1.3$ quantum Hall transition regime. 
実験で観測された光応答信号は，両者の足し合わせとして，

$$
\Delta V=V_{\text {photovoltaic }}+\frac{\partial R}{\partial T} \Delta T \cdot I_{\mathrm{SD}}
$$

と記述できる。これまでに $\mathrm{SiO}_{2}$ 上のグラフェン量子ホール 系で報告されている中赤外光応答 ${ }^{14,15)}$ は，いずれもボロメト リック効果を利用して光検出を行っている. 一方, サイクロ トロン吸収に起因する光起電力効果は高移動度グラフェン/ h-BNを用いることで初めて観測された現象である7). 光起 電力発生のメカニズムは今後の考察が必要であるが, 外部磁 場の反転により光起電力の極性が系統的に変化するため, 量 子ホール端状態伝導と深い関連がある.

Fig. 8 は $I=100 \mathrm{nA}$ に打ける光応答信号 $\Delta V$ の温度依存 性である.ボロメトリック効果による光応答は温度上昇とと もに急激に減少し， $T=70 \mathrm{~K}$ 以上では光応答は観測できな かった。これは $\partial R / \partial T$ の温度变化を反映していると考えら れる. 一方, サイクロトロン吸収に起因する光起電力効果 は，信号強度が最大值となる $T=25 \mathrm{~K}$ 以上では温度の上昇 とともに緩やかに減少するが， $T=180 \mathrm{~K}$ でも観測されてい る.この結果は， $77 \mathrm{~K}$ 以上の実用的な低温域で動作する高 感度中赤外光検出器としての可能性を示唆している．例えば 半導体低次元電子系に拈けるサイクロトロン吸収を利用した 単一光子検出 ${ }^{13)}$ には $100 \mathrm{mK}$ 以下の極低温が要求されるが, 動作温度と検出波長域の狭さという課題をグラフェン/h$\mathrm{BN}$ 量子ホール系の利用により解決できる可能性があること を示唆している.

\section{4. 単原子層 h-BN トンネルバリアを利用したグ ラフェンへのスピン注入}

グラフェンはスピン軌道相互作用や超微細相互作用が弱く スピン緩和時間が長いと期待されるため，スピントロニクス に打けるスピン伝導層としても有望と考えられている16). 既に，単層グラフェン，二層グラフェンにおいてナノ秒を超 えるスピン緩和時間と大きなスピン拡散長が実験的に示され ている17-19).これまでの実験では, 強磁性電極とグラフェ ンの間にトンネルバリアを挿入することにより電気的なスピ ン注入とスピン検出が達成されてきた ${ }^{20-23)}$. しかしなが

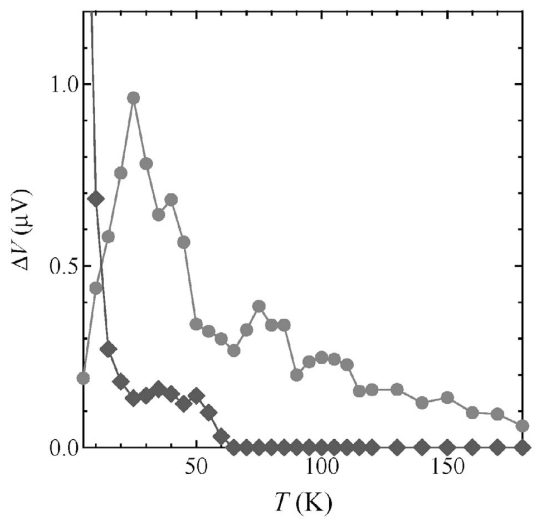

Fig. 8 Temperature dependence of the photoresponse measured with $I=100 \mathrm{nA}$. (a) $v=2.0$. (b) $v=1.3$.
ら，トンネルバリアを通してグラフェンに注入されるスピン の偏極率は数十パーセント程度であり, 十分に高いとは言え ない。磁気不揮発メモリ等で使用されているトンネル磁気抵 抗素子に抢いては，トンネルバリアに結晶性の酸化マグネシ ウムを用いることにより $90 \%$ 近いスピン偏極率が実現され ている24,25)。従って，グラフェンに対しても結晶性のトンネ ルバリアを利用することで，より高効率なスピン注入が実現 できる可能性がある。

本節では，メカニカル䢃開法とドライ転写法を用いて単原 子層 h-BNトンネルバリアを強磁性体とグラフェンの間に 作製し，四端子非局所磁気抵抗測定によりグラフェンへのス ピン注入を確認する。

\section{$4.1 \mathbf{h}-\mathrm{BN}$ 単原子層トンネルバリアの作製}

メカニカル䢃開とドライ転写法を用いて $\mathrm{h}-\mathrm{BN}, \mathrm{MoS}_{2}$, $\mathrm{WS}_{2}$ 等の原子層結晶トンネルバリアをグラフェン上に作製 できることが相次いで報告されている26-30)。これら原子層 結晶は，(i) 䢃開法により単原子層単位で厚さ制御が可能, (ii) 単結晶トンネルバリアとして利用が可能, (iii) 材料の選択 によって幅広いバンドギャップが得られる等，トンネルバリ ア利用に抢ける優れた利点がある。原子層結晶トンネルバリ アを用いたスピン注入の実現は，グラフェンスピントロニク スの発展に向けた重要な技術である.

本研究では， $6 \mathrm{eV}$ 程度の大きなバンドギャップを持ち, グラフェンとの格子不整合が非常に小さい h-BNをトンネ ルバリアとして利用した. h-BN は前述のようにグラフェン の高移動度化を実現する基板（下地）として利用可能な層状 化合物である. Fig. 9 (a) は強磁性 $\mathrm{Ni}_{81} \mathrm{Fe}_{19} /$ 単原子層 h$\mathrm{BN} /$ 二層グラフェン/h-BN の構造を有するグラフェンスピ ンバルブ素子の模式図であり，Fig. 9(b)は素子の SEM 写 真である. 伝導チャネル幅は $1 \mu \mathrm{m}$ であり, 強磁性電極の幅 は270 nm, $580 \mathrm{~nm}, 380 \mathrm{~nm}$, 電極間距離は600 nm である.

Fig. 10 (a) は単原子層 h-BN を介した面直伝導の電流-電 圧 $(I-V)$ 特性を示している. 測定温度は $30 \mathrm{~K}$ であり, $n^{+-}$

(a)

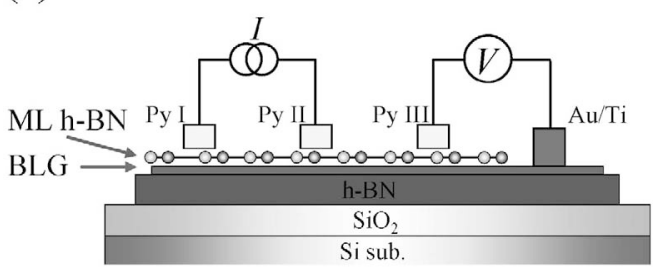

(b)

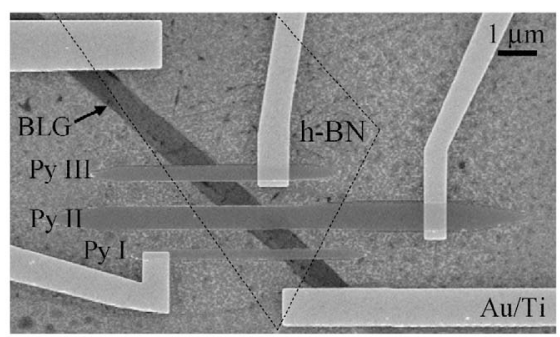

Fig. 9 (a) Schematic illustration of the graphene spin valve device and the four-terminal nonlocal magnetoresistance measurement configuration. (b) A SEM image of the device. 
(a)

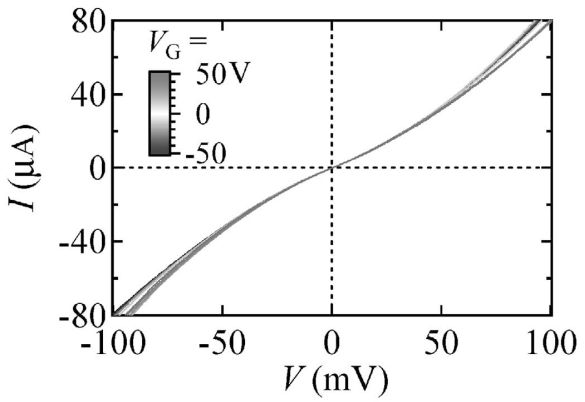

(b)

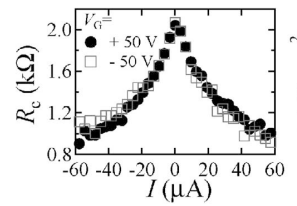

(c)

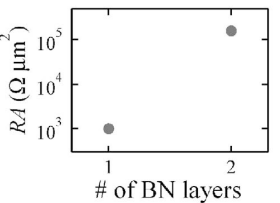

Fig. 10 (a) Three-terminal $I-V$ curve for the ferromagnetic contact at $30 \mathrm{~K}$. (b) The current dependence of the junction resistance. (c) The layer number dependence of the junction resistance at $30 \mathrm{~K}$.

$\mathrm{Si}$ 基板に印加するバックゲート電圧 $V_{\mathrm{G}}$ を変化させながら測 定を行った。非線形な $I-V$ 特性を示しており，微分抵抗 $(d V / d I)$ のバイアス電流に対する変化は Fig. 10 (b) に示す 通りである。ゼロバイアスでの素子抵抗 $R A$ は扰そ 1 $\mathrm{k} \Omega \mu \mathrm{m}^{2}$ 程度である. 2 原子層 $\mathrm{h}-\mathrm{BN}$ に関しても同様な素子 を作製し， $R A=160 \mathrm{k} \Omega \mu \mathrm{m}^{2}$ という值を得ている． Fig. 10 (c)に示すように, $\mathrm{h}-\mathrm{BN}$ の原子層数が 1 層増えると, $R A$ は100倍程度増加する. この様な原子層数に対する抵抗の変 化率はマンチェスター大学のグループが報告したグラフェ ン/h-BN/グラフェントンネル素子の結果と良い一致を示し ている ${ }^{26)}$. RA は温度の上昇とともに単調に減少するトンネ ルバリア的な振る舞いを示し, $300 \mathrm{~K}$ での $R A$ は $1.6 \mathrm{~K}$ での

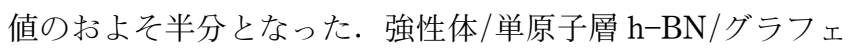
ントンネル接合の作製に成功したことを示している.

\section{2 グラフェンへのスピン注入}

Fig. 11(a) は単原子層 h-BN バリアを有するグラフェンス ピンバルブ素子を用いた四端子非局所配置における磁気抵抗 測定の結果である. 外部磁場はグラフェン面内方向に印加さ れ，バックゲート電圧 $V_{\mathrm{G}}=+50 \mathrm{~V}$ ，バイアス電流 $I=+50$ $\mathrm{mA}$, 温度 $30 \mathrm{~K}$ 及び $300 \mathrm{~K}$ の条件で測定している. 図中の矢 印は左から順に 3 つ強磁性電極 (PyI, PyII, PyII) の磁化 方向を示している. 強磁性体の磁化反転に対応した磁気抵抗 効果が観測されており, 単原子層 h-BNを介したグラフェ ンへのスピン注入およびスピン検出を実現したことを示して いる。さらに，磁場を面直方向に印加することにより， Hanle 効果測定を行った（Fig. 11(b)). スピンの歳差運動 に対応する明瞭な Hanle 効果が観測されており, 単原子層 h-BN を通じたグラフェンへのスピン注入実現を確証してい る.

本実験では, メカニカル䢃開法と原子層転写技術を利用し て原子層数制御をしながら作製した強磁性金属/単原子層 $\mathrm{h}$ $\mathrm{BN} /$ グラフェンスピンバルブ素子構造に拈いて電気的スピン
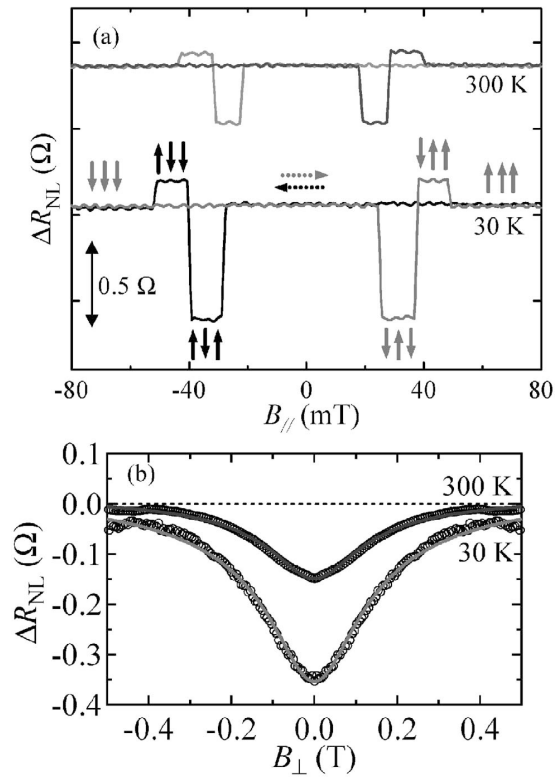

Fig. 11 (a) Nonlocal magnetoresistance measured at $300 \mathrm{~K}$ and $30 \mathrm{~K}$. The solid arrows indicate the magnetization direction of Py1, Py2, and Py3 (from right to left). (b) Hanle effect measurements under a perpendicular magnetic field.

注入が実現されている，様々な材料の原子層膜トンネルバリ アを利用したスピン注入の可能性があり, 今後の複合原子層 スピントロニクスへの展開が期待できる.

\section{5. まとめと今後の展望}

本稿では，メカニカル䢃開と原子層転写法によるグラフェ ン $/ \mathrm{h}-\mathrm{BN}$ 複合構造の作製, 強磁場中でのサイクロトロン吸 収に起因する光起電力効果の観測 ${ }^{6)}$, 単原子層 h-BN トンネ ルバリアを利用したグラフェンへのスピン注入の実現7)につ いて紹介した．グラフェンを用いた超高感度中赤外光検出器 が実現できれば，グラフェンを利用したテラヘルツ光源・ レーザ・検出素子の研究開発 ${ }^{31-35)}$ 等と融合し, グラフェン オプトエレクトロニクスへの展開が期待される. またグラフ ェンヘのスピン注入技術の確立は, グラフェンスピントロニ クスへの展開に向けた重要な要素技術として期待される.

最近では, グラフェンおよび $\mathrm{h}-\mathrm{BN}$ に加え, 半導体 $\left(\mathrm{MoS}_{2}, \mathrm{WS}_{2}, \mathrm{WSe}_{2}\right)$, 超伝導体 $\left(\mathrm{NbSe}_{2}\right)$, トポロジカル絶 縁体 $\left(\mathrm{Bi}_{2} \mathrm{Te}_{3}\right)$ などの原子層薄膜が作製されて抢り，それら の組み合わせも検討されている. 筆者らも $\mathrm{h}-\mathrm{BN} /$ グラフェ ン/h-BNファンデルワールスヘテロ構造における量子ホー ル物性 36 ) 金属 $/ \mathrm{MoS}_{2} /$ グラフェン縦型 FET における電流 変調37)など, 基礎・応用の両面で研究を進めている. 複合 原子層における新規物性の発現や新機能素子の実現を目指し た原子層科学の発展を期待したい.

\section{謝辞}

本研究の推進には, 文部科学省科学研究費補助金新学術領 域「原子層科学」, 科学技術振興機構戦略的創造研究推進事 業さきがけ, 文部科学省科学研究費補助金, 文部科学省イノ ベーションシステム整備事業の支援を受けた. 


\section{〔文献〕}

1) K. S. Novoselov, A. K. Geim, S. V. Morozov, D. Jiang, M. I. Katsnelson, I. V. Grigorieva, S. V. Dubonos and A. A. Firsov: Nature, 438 (2005) 197.

2) A. F. Young and P. Kim: Nature Phys., 5 (2009) 222.

3) K. S. Novoselov, Z. Jiang, Y. Zhang, S. V. Morozov, H. L. Stormer, U. Zeitler, J. C. Maan, G. S. Boebinger, P. Kim and A. K. Geim: Science, 315 (2007) 1379.

4) K. Bolotin, K. Sikes, Z. Jiang, M. Klima, G. Fudenberg, J. Hone, P. Kim and H. Stormer: Solid State Commun., 146 (2008) 351.

5) N. Savage: Nature, 483 (2012) S30.

6) S. Masubuchi, M. Onuki, M. Arai, T. Yamaguchi, K. Watanabe, T. Taniguchi and T. Machida: Phys. Rev. B, 88 (2013) 121402

7) T. Yamaguchi, T. Inoue, S. Masubuchi, S. Morikawa, M. Onuki, K. Watanabe, T. Taniguchi, R. Moriya and T. Machida: Appl. Phys. Express, 6 (2013) 073001.

8) J. H. Chen, C. Jang, S. Xiao, M. Ishigami and M. S. Fuhrer: Nature Nanotech., 3 (2008) 206.

9) C. R. Dean, A. F. Young, I. Meric, C. Lee, L. Wang, S. Sorgenfrei, K. Watanabe, T. Taniguchi, P. Kim, K. L. Shepard and J. Hone: Nature Nanotech., 5 (2010) 722.

10) S. Masubuchi, K. Iguchi, T. Yamaguchi, M. Onuki, M. Arai, K. Watanabe, T. Taniguchi and T. Machida: Phys. Rev. Lett., 109 (2012) 036601.

11) S. Masubuchi, S. Morikawa, M. Onuki, K. Iguchi, K. Watanabe, T. Taniguchi and T. Machida: Jpn. J. Appl. Phys., 52 (2013) 110105

12) Y. Kawano, Y. Hisanaga, H. Takenouchi and S. Komiyama: J. Appl. Phys., 89 (2001) 4037.

13) S. Komiyama, O. Astafiev, V. Antonov, T. Kutsuwa and H. Hirai: Nature, 403 (2000) 405.

14) R. S. Deacon, K. C. Chuang, R. J. Nicholas, K. S. Novoselov and A. K. Geim: Phys. Rev. B, 76 (2007) 081406.

15) N. G. Kalugin, L. Jing, W. Bao, L. Wickey, C. Del. Barga, M. Ovezmyradov, E. A. Shaner and C. N. Lau: Appl. Phys. Lett., 99 (2011) 013504

16) W. Han, K. M. McCreary, K. Pi, W. H. Wang, Y. Li, H. Wen, J. R. Chen and R. K. Kawakami: J. Magn. Magn. Mater., 324 (2012) 369

17) W. Han and R. K. Kawakami: Phys. Rev. Lett., 107 (2011) 047207.

18) T. Y. Yang, J. Balakrishnan, F. Volmer, A. Avsar, M. Jaiswal, J. Samm, S. R. Ali, A. Pachoud, M. Zeng, M. Popinciuc, G. Güntherodt, B. Beschoten and B. Özyilmaz: Phys. Rev. Lett., 107 (2011) 047206
19) B. Dlubak, M.-B. Martin, C. Deranlot, B. Servet, S. Xavier, R. Mattana, M. Sprinkle, C. Berger, W. A. De Heer, F. Petroff, A. Anane, P. Seneor and A. Fert: Nat. Phys., 8 (2012) 557.

20) N. Tombros, C. Jozsa, M. Popinciuc, H. T. Jonkman and B. J. van Wees: Nature, 448 (2007) 571.

21) W. Han, K. Pi, K. M. McCreary, Y. Li, J. J. I. Wong, A. G Swartz and R. K. Kawakami: Phys. Rev. Lett., 105 (2010) 167202.

22) A. Avsar, T.-Y. Yang, S. Bae, J. Balakrishnan, F. Volmer, M. Jaiswal, Z. Yi, S. R. Ali, G. Güntherodt, B. H. Hong, B. Beschoten and B. Özyilmaz: Nano Lett., 11 (2011) 2363.

23) T. Yamaguchi, S. Masubuchi, K. Iguchi, R. Moriya and T. Machida: J. Magn. Magn. Mater., 324 (2012) 849.

24) S. Yuasa, T. Nagahama, A. Fukushima, Y. Suzuki and K. Ando: Nat. Mater., 3 (2004) 868.

25) S. S. P. Parkin, C. Kaiser, A. Panchula, P. M. Rice, B. Hughes, M. Samant and S.-H. Yang: Nat. Mater., 3 (2004) 862.

26) L. Britnell, R. V. Gorbachev, R. Jalil, B. D. Belle, F. Schedin, M. I. Katsnelson, L. Eaves, S. V. Morozov, A. S. Mayorov, N. M. R. Peres, A. H. Castro Neto, J. Leist, A. K. Geim, L. A Ponomarenko and K. S. Novoselov: Nano Lett., 12 (2012) 1707.

27) L. Britnell, R. V. Gorbachev, R. Jalil, B. D. Belle, F. Schedin, A. Mishchenko, T. Georgiou, M. I. Katsnelson, L. Eaves, S. V. Morozov, N. M. R. Peres, J. Leist, A. K. Geim, K. S. Novoselov and L. A. Ponomarenko: Science, 335 (2012) 947.

28) T. Georgiou, R. Jalil, B. D. Belle, L. Britnell, R. V. Gorbachev, S. V. Morozov, Y.-J. Kim, A. Gholinia, S. J. Haigh, O. Makarovsky, L. Eaves, L. A. Ponomarenko, A. K. Geim, K. S. Novoselov and A. Mishchenko: Nat. Nanotech., 8 (2013) 100.

29) M. S. Choi, G.-H. Lee, Y.-J. Yu, D.-Y. Lee, S. Hwan Lee, P. Kim, J. Hone and W. Jong Yoo: Nat. Commun., 4 (2013) 1624.

30) W. J. Yu, Z. Li, H. Zhou, Y. Chen, Y. Wang, Y. Huang and X. Duan: Nat. Mater., 12 (2013) 246.

31) V. Ryzhii, T. Otsuji, M. Ryzhii and M. S. Shur: J. Phys. D, 45 (2012) 302001.

32) A. Satou, V. Ryzhii, Y. Kurita and T. Otsuji: J. Appl. Phys., 113 (2013) 143108

33) A. A. Dubinov, V. Ya Alechkin, V. Mitin, T. Otsuji and V. Ryzhii: J. Phys. Cond. Mat., 23 (2011) 145302.

34) T. Watanabe, T. Fukushima, Y. Yabe, S. A. Boubanga Tombet, A. Satou, A. A. Dubinov, V. Ya Aleshkin, V. Mitin, V. Ryzhi and T. Otsuji: New. J. Phys., 15 (2013) 075003.

35) V. Ryzhii, M. Ryzhii, V. Mitin, M. S. Shur, A. Satou and T. Otsuji: J. Appl. Phys., 113 (2013) 174506.

36) S. Morikawa, S. Masubuchi, R. Moriya, K. Watanabe, T. Taniguchi and T. Machida: (submitted).

37) R. Moriya, T. Yamaguchi, Y. Inoue, S. Morikawa, Y. Sata, S. Masubuchi and T. Machida: Appl. Phys. Lett., 105 (2014) 083119. 